\title{
EKOLOGI LINGKUNGAN DAN KESEHATAN MASYARAKAT KARESIDENAN BANYUMAS MASA KOLONIAL
}

\section{Dina Dwikurniarini*}

\begin{abstract}
Abstrak
Musim kemarau merupakan keadaan yang lebih banyak mendatangkan kerugian daripada keuntungan. Di Karesidenan Banyumas dalam musim kemarau terjadi banyak genangan air yang menjadi sarang nyamuk, sehingga terjadi wabah penyakit malaria. Penyakit itu rupanya masih tetap ada hingga masa pemerintahan RI. Bagaimana sebenarnya masalah tersebut bermula dan bagaimana penanganan dan pencegahan dan model pencegahan seperti apa yang sudah dilakukan pemerintah. Dari data sejarah kolonial menunjukkan bahwa penyakit itu sudah lama membawa korban sehingga dikeluarkan Ordonansi Pes 1902. Pada sebagian besar wilayah Banyumas abad 19 memang sering terjadi berbagai epidemi. Dapatkah kita belajar dari masa lalu untuk mengatasi masalah saat ini ataukah masa lalu dibiarkan berlalu saja terutama untuk kasus yang sudah lebih dari satu abad lalu.
\end{abstract}

Kata Kunci: Banyumas, Ekologi, Kesehatan, dan Ordonansi Pes.

\section{A. Pendahuluan}

Karesidenan Banyumas sejak 1 Januari 1936 willayahnya meliputi kabupaten-kabupaten Banyumas, Cilacap, Purbalingga Banjarnegara ${ }^{1}$. Karesidenan Banyumas merupakan daerah yang tanahnya berbentuk oval dan membentang dari Timur ke Barat diantara gunung-gunung, bukit-bukit dan dibelah oleh sungai Serayu. Bagian Utara dan Timur Laut merupakan perbukitan. Garis batas Utara melalui puncak gunung Praba dan gunung Slamet yang terbelah oleh aliran sungai yang bermuara di laut Jawa dan Samudra Hindia $^{2}$. Dengan pegunungan sebagai pemisah, maka lereng Selatan merupakan bagian terbesar dari wilayah Karesidenan Banyumas. Daerah sebelah Timur menuju ke pegunungan Daya Luhur dan sungai Serayu dan dipisahkan rawa-rawa dan jalan ke Nusa Kambangan ${ }^{3}$. Dengan demikian bagian terbesar Karesidenan Banyumas bagian Timur hampir seluruhnya

*Dosen Prodi Ilmu Sejarah Jurusan Pendidikan Sejarah FISE UNY.

${ }^{1}$ L.M. Gondosubroto, Kenang-kenangan 1933-1950. (Purwokerto: tanpa penerbit 1992), hlm. 17-18.

${ }^{2}$ P. Beeker. “ Fragmenten Eener Reis Over Java Door Binnenland van Midden Java Hoofdstuk XIII Poerworedjo naar Banjoemas” dalam Tijdschrijf voor Nederlandsch Indie II adl. 7, 1850, hlm. 86.

${ }^{3}$ Ibid. 
merupakan perairan Serayu yang bercabang-cabang kesumbernya di gununggunung tersebut dan disitulah sebagian besar penduduk bertempat tinggal.

Berdasar ekologi lingkungan, Karesidenan Banyumas merupakan wilayah yang cukup subur. Akan tetapi kondisi lingkungan telah menimbulkan masalah dikemudian hari. Permasalahan hidup yang utama adalah hubungan antara mahkluk hidup khususnya manusia dengan lingkungannya. Masalahan lingkungan pada hakikatnya antroposentris karena permasalahnya dilihat dari kepentingan manusia. Bumi sebagai ekosistem yang maha besar dengan organisme autotropik dan heterotropik hidup didalamnya dan saling tergantung. Jika dilihat dari komponennya ekosistem terdapat: 1) komponen abiotik, 2) organisme produsen, 3) organisme konsumen, 4) organisme perombak. Manusia termasuk organisme konsumen, maka kehidupannya sangat tergantung pada lingkungan.

Populasi manusia di bumi dapat mempengaruhi daya dukung lingkungan, karena ruang dan tersedianya bahan yang diperlukan cenderung terbatas. Alam sekalipun dapat memberikan hasil maksimal tetapi juga memberi suatu tekanan yang disebut environmental resistance ${ }^{4}$. Apabila terjadi perubahan yaitu menyesuakan dengan pertumbuhan populasi, maka titik keseimbangan baru akan terbentuk. Ini berarti daya dukung lingkungan tidak tetap karena akan menyesuaikan dengan perubahan lingkungan. Perubahan yang terjadi karena cuaca, iklim, pembakaran, banjir, gempa bumi dan vulkanisme.

Faktor lingkungan dapat diklasifikasikan sebagai faktor biologis, sosial dan fisik ${ }^{5}$. Faktor lingkungan biologis meliputi: 1) agen pembawa penyakit, 2) tempat infeksi (orang, binatang, tanah), 3) vektor penyebar penyakit (nyamuk, lalat, cacing, tikus), 4) tumbuhan dan binatang (sumber makanan, anti biotik, prinsip pengobatan). Lingkungan sosial merupakan keseluruhan organisme kemasyarakatan yang secara relevan mempengaruhi teknis dan rawatan, penerimaan pemikiran baru mengenai kesehatan baik oleh dokter maupun tenaga medis lain. Lingkungan fisik menyangkut panas, sinar matahari, udara, air, radiasi, dan bahan kimia.

${ }^{4}$ Soedjiran Reksosudarmo, dkk. Pengantar Ekologi. (Bandung: Remaja Karya, 1987), hlm,. 36.

${ }^{5}$ Mausner \& Bahn. Epidemiology an Introductory Text. (Philadelphia: WB Sanders Company, 1985). hlm. 30. 
Setiap sumber daya alam mempunyai karakteristik yang khusus terutama dalam hubungannya dengan ekosistem dan pembangunan ${ }^{6}$. Tanah sebagai salah satu sumber daya alam jika subur menjadi potensial untuk penopang hidup manusia. Lingkungan berfungsi sebagai perlindungan, menopang lingkungan serbaguna, produksi dan pemukiman, tanah akan menjadi maksimal jika keempat fungsi tersebut saling berkaitan.

Sungai-sungai di Jawa membawa sedimen yang menyebabkan kesuburan tanah sekitarnya ${ }^{7}$, tetapi pada awal abad ke 20 sudah terjadi degradasI lingkungan. Memang eksploitasi lingkungan bukan satu-satunya penyebab berubahnya kondisi lingkungan Jawa. Akan tetapi faktor-faktor pertumbuhan penduduk, perluasan lahan pertanian, adaptasi penemuan baru serta perkembangan teknologi menejemen baru ikut mempengaruhi landscape alami dan itu telah dimulai sejak 1850 bahkan diperkirakan sejak tahun $1500^{8}$. Lingkungan Banyumas mulai memudar setelah terjadi eksploitasi wilayah oleh kolonial terutama pembukaan lahan areal perkebunan, pemukiman dan industri.

\section{B. Wabah Penyakit di Banyumas}

Wabah penyakit sangat menakutkan manusia karena dapat menular dengan cepat diantara manusia penderita ke manusia sehat bahkan merambah dengan cepat ke wilayah sekitarnya. Penyakit yang telah memakan banyak korban yaitu: 1) pes, 2) malaria, 3) kolera, 4) typhus, 5) desentri, 6) cacar, 7) cacing, 8) frambosia (radang paru). Penyakit-penyakit tersebut tidak dapat digolongkan sebagai penyakit tropis, tetapi merupakan penyakit dunia yang dapat timbul dimana-mana ${ }^{9}$. Keganasan suatu penyakit terlihat pada banyaknya korban yang terkena.

Tidak semua penyakit berasal dari Asia, tetapi sebagian penyakit adalah jenis baru yang terjadi karena kontak pelayaran dengan pelaut dan tentara Barat. Kontak perdagangan Eropa dan Asia sudah lama terjalin melalui jalan

\footnotetext{
${ }^{6}$ Moh. Suryani dan Bahrin Somad (penyunting). Manusia dalam Keserasian Lingkungan. (Jakarta: Fakultas Ekonomi UI, 1983). hlm. 12.

${ }^{7}$ Peter Boomgard. Paper landschapes Exploration in the Environmental Histyory of Indonesia. (Leiden: KITLV Press, 1997). hlm. 29.

${ }^{8}$ Ibid. hlm. 91

${ }^{9} \mathrm{P}$. Paverelli. De Zorg Voorde Volks Gezondhett in Nederlandsch-Indie. (S’Gravenhage:Mitgeverij W van Hoewe,tt). hlm. 10.
} 
darat jauh sebelum ekspedisi kelautan abad ke 16 dan $17^{10}$. Penyakit baru adalah siphilis yang di impor dari Amerika ke Eropa yang menyertai ekspedi kelautan dan militer ke Asia, tetapi tidak sampai tahap epidemi.

Wabah kolera, malaria, cacar dan kelaparan merupakan wabah asli Asia. Malaria penyebarannya ditunjang oleh proyek irigasi orang Eropa dan perluasan perkebunan ${ }^{11}$. Dengan demikian keempat penyakit lokal tersebut telah mewabah di Jawa dan penyebaranya ditunjang oleh kelaparan setelah kedatangan Belanda. Peristiwa tersebut terjadi pada tahun-tahun 1624-1627, 1664-1665, 1674-1677 yang sebagian besar juga disebabkan oleh kekeringan, banjir, perang dan kegagalan panen. Jika dilihat dari penyebab wabah penyakit dapat ditimbulkan oleh 1) bakteri, 2) virus, 3) protozoa.

Epidemi yang melanda Banyumas dapat dikategorikan dalam 4 periode yaitu 1) periode 1870-1890, 2) 1891-1921, 3) 1921-1930, 4) 1931-1940. Dalam periode pertama, demam malaria menyerang hampir seluruh wilayah Karesidenan. Tahun 1873 penderita malaria mencapai 7.149 orang dan Cilacap yang paling banyak korbannya, tahun yang sama juga timbul penyakit kolera yang menyerang 1.000 penderita dan 563 meninggal. Cacar selama tahun 1870-1871 menyerang 618 jiwa yang terbanyak dari Cilacap. Sampai Desember 1883 tidak kurang dari 41.070 orang terkena malaria dan yang meninggal 5\% atau 2.054 orang $^{12}$. April 1884 penderita malaria masih 115 orang $^{13}$.

Periode kedua, ada kesamaan penyakit yang mewabah. Malaria menyerang Purbalingga, Maos, Cilacap, Banyumas, Majenang pada tahun 1908 dengan 28.903 penderita yang meninggal 3.410 orang. Tahun 1911 dari 34.008 penderita yang meninggal 4.400 orang yang terbesar di Cilacap yaitu 16.417 penderita yang meninggal 1983 orang $^{14}$. Penyakit cacar masih muncul tahun 1908 dan menyerang 1.213 orang dengan kematian 114 dan pada tahun 1911 menyerang 18 orang dan meninggal semua ${ }^{15}$. Penyakit kulit, kelamin dan pernafasan termasuk sering menyerang penduduk tertama karena faktor

\footnotetext{
${ }^{10}$ Peter Boomgard. "The Development of Colonial Health Care in Java: an Exploratory Introduction”, Bijdragen tot de Taal Land-en Volkenkunde KITLV 1993, deel 149. hlm. 79.

${ }^{11}$ Ibid.

${ }^{12}$ Algemene Verslag 1883, Arsip Banyumas No. 1910 (ANRI)

${ }^{13}$ Algemene Verslag 1883, Arsip Banyumas No. 1911 (ANRI)

14،"Residentie Banjoemas. Geneeskundig Tijdsrijft voor Nederlandsch-Indie. Batavia: Javasche Boekhandel \& Drukkerij, 1911, hal. 45.

${ }^{15}$ Ibid.
} 
kebersihan. Dari seluruh penderita yang berobat mencapai 6.153 orang $^{16}$. Penyakit akibat keracunan juga terjadi pada tahun 1911.

Periode ketiga, pada 1923 Banjarnegara diserang pes sebanyak 26.642 orang, 622 orang diantaranya terkena pes paru-paru dan hampir semua korbannya meninggal ${ }^{17}$. Malaria menyerang 60,000 orang Cilacap dan Banyumas tahun 1925, 1926-1927 menyerang Karangkobar dan Pejarawan ${ }^{18}$. Desentri menyerang pada tahun 1924 di Banyumas dengan 206 penderita, dan 488 penderita di Purbalingga.

Periode keempat, penyakit malaria masih belum dapat diatasi tetapi tidak seganas periode-periode sebelumnya. Pes, typhus juga menyerang tetapi tidak banyak, juga terdapat kasus kurang gizi di Purwajati yang menimpa 10\% penduduk. Malaria dan cacing juga menyerang penduduk.

\section{Ekologi Lingkungan Banyumas}

Melihat berbagai penyakit yang menyerang Karesidenan Banyumas, hampir semua wilayah terkena wabah. Jika dilihat dari sumber dan penyebaran penyakit, maka faktor lingkungan juga ikut andil disini. Lingkungan Banyumas sangat relevan sebagai tempat berkembangnya nyamuk anopheles ludlowi, yaitu di daerah sungai yang kering pada musim kemarau, daerah pantai dan rawa-rawa. Secara umum lingkungan Banyumas tidak menguntungkan terutama jika musim kemarau panjang. Sebaliknya musim hujan terus menerus seperti yang terjadi pada 1908 selama 187 hari dilaporkan telah menyebabkan penyakit demam ${ }^{19}$. Kondisi makin buruk jika terjadi banyak angin dan udara yang lembab. Perubahan lingkungan membantu penyebaran penyakit makin cepat terutama dibidang transportasi dan perluasan tanah garapan ${ }^{20}$.

Wilayah Banyumas dibedakan antara daerah pantai dan pedalaman. Daerah pedalaman yang subur ada disekitar lembah Serayu merupakan tanah pertanian dan perkebunan, sedangkan pelabuhan Cilacap merupakan wilayah perdagangan dan transportasi. Wilayah sekitar muara sungai Serayu terdapat

${ }^{16}$ Residentie Banjoemas. Geneeskundig Tijdsrijft voor Nederlandsch-Indie. Batavia:: Bruning \& Wijt, 1906. hlm. 630.

${ }^{17}$ Memori Serah Jabatan 1921-1930 Jawa Tengah000. (Jakarta:ANRI 1997). hlm. CVII, CXIL.

${ }^{18}$ Ibid. hlm. CVII, CIX, CX.

${ }^{19}$ Ibid.

${ }^{20}$ Norman G Owen. Death and Desease in South Easth Asia. (Singapore: Oxford University Press, 1987). hlm. 64. 
bukit pasir yang terpotong oleh banyak sungai yang mengalir dari Utara ke Selatan, sehingga menyebabkan pengendapan lumpur di muara sungai. Pada saat air pasang terbentuk genangan air, sehingga menjadi tempat berkembangbiaknya nyamuk ludlowi ${ }^{21}$. Untuk mengurangi masalah di sungai Bengawan dan Telomoyo (keduanya di Karanganyar) ketika tinggi air perbukitan lebih tinggi dari waktu air surut maka permukaan sungai itu digali ${ }^{22}$.

Wilayah pantai di Karesidenan Banyumas tidak ada yang merupakan perbukitan kecuali Nusakambangan yang berbukit batu yang dipisahkan oleh laut dan daratan. Bagian Timur Serayu dan Jeruk Legi merupakan daerah rawarawa yang jauh dari laut dan tidak berpenghuni. Sebaliknya Daya Luhur sebagian besar wilayahnya merupakan delta berawa yang setiap tahun terkena aliran lumpur sungai ${ }^{23}$. Kedua wilayah Banyumas baik pedalaman maupun pantai merupakan daerah sarang nyamuk malaria.

Distrik Cilacap mempunyai banyak daerah rendah, sehingga banyak genangan air, rawa-rawa kecil dan besar maupun pembuangan air yang menggenang sepanjang perbukitan di Teluk Penyu ${ }^{24}$. Dengan kondisi seperti itu menjadikan daerah Cilacap sering mengalami epidemi malaria dan merupakan peristiwa terbesar di Karesidenan Banyumas.

Epidemi malaria di Karesidenan Banyumas pertama berjangkit di lembah Serayu dan terbesar terjadi pada tahun 1845, 1847, dan 1848 dengan menelan korban 328.000 jiwa $^{25}$. Keadaan itu terjadi karena wilayah tersebut merupakan pemukiman terpadat, sedangkan wilayah Cilacap mulai banyak dihuni dengan berkembangnya pelabuhan Cilacap. Malaria pantai lebih ganas daripada malaria pedalaman dan terjadi setiap musim kemarau.

Lingkungan Cilacap menjadi daerah penyebab malaria yang setiap tahun berjangkit dan dipastikan setiap lima tahun terjadi epidemi besar dengan menelan ratusan korban ${ }^{26}$. Apa yang terjadi di Cilacap relevan dengan pendapat Peter Boomgaard, bahwa perkembangan daerah pelbuhan Cilacap

\footnotetext{
${ }^{21}$ Memori van Overgave 1932. Arsip Nasional RI Rel 6e. hlm. 59.

${ }^{22}$ Ibid. hlm. 60.

${ }^{23}$ P Bleecker, op.cit. hlm. 87.

${ }^{24}$ Ibid.

${ }^{25}$ Ibid.
}

${ }^{26}$ G.W. Kiewiet de Jonge. “Tjilatjap als Malariahaard” Geneeskundige Tijdschriijft voor Nederlandsch-Indie, Deel XLII. Batavia: Java Boekh \& Drukkerij, 1902. hlm. 285. 
maupun kondisi alamnya merupakan faktor utama terjadinya epidemi malaria $^{27}$.

\section{Kebijakan Pemerintah Kolonial}

Melihat wabah-wabah yang melanda Karesidenan Banyumas dan kondisi lingkungannya sangat relevan dengan kasus-kasus penyakit yang bahkan sampai menimbulkan epidemi. Dalam periode yang cukup lama lebih dari 30 tahun kekuasaan Belanda (sejak liberalisasi) tidak menunjukka usaha penanggulangan dari pemerintah.

Untuk mengurangi penyebaran penyakit dan kematian karena wabah penyakit, maka pemerintah mengeluarkan Ordonansi Pes tahun 1902 No. 112 dan disempurnakan dengan ketentuan tambahan No. 395 tahun 1903, No. 434 tahun 1904, No, 409 tahun 1904, No 24 tahun 1905, No. 116 tahun 1905. Peraturan No. 299 tantang Ordonansi Epidemi dan Ordonansi Bedah Mayat. Peraturan Perundang Undangan lain: ${ }^{28}$ 1) Peraturan Mengenai Jawatan Kesehatan Rakyat tahun 1882 yang berubah sejak 1911. 2) Ordonansi Wabah Sampar (pes), Kolera, Cacar, Difteria dan Typhus tahun 1911, 3) Ordonansi Karantina tahun 1911, 4) Perundang Undangan untuk Pemeriksaan Mayat untuk Pribumi dan Timur Asing tahun 1916, 5) Ordonansi mengenai Jemaah Haji tahun 1922.

Kesehatan Hindia mula-mula ditangani oleh militer Geneeskundige Dienst 1808, Burgelijke Geneeskundige Dienst (BGD) atau Jawatan Kesehatan Sipil 1820 yang tahun 1825 Dienst der Volkgezondheid atau Jawatan Kesehatan rakyat $^{29}$. Dinas-dinas tersebut meliputi Dinas Sanitasi, Karantina, Pemberantasan Malaria, Pemberantasan sampar, Propaganda Higiene, Institute Pasteur dan Lembaga Pembuatan Vaksin Cacar, Laboratorium Kesehatan Pusat, Urusan Pendidikan, Rumah Sakit Umum Pusat, Rumah Sakit Jiwa. Ketentuan yang dikeluarkan juga menyangkut Peraturan No. 167 tahun 1900 mengenai Air Minum Pelabuhan Cilacap dan Banyumas ${ }^{30}$.Ordonansi Pes dikeluarkan khusus untuk pencegahan dan pengekangan penyakit pes dimulai di daerah pelabuhan, karena kapal-kapal menjadi tempat bersarang tikud pembawa penyakit pes. Peraturan menetapkan bahwa kapal paling dekat 50

\footnotetext{
${ }^{27}$ G. Owen. op. cit. hlm. 75.

${ }^{28}$ Depkes RI. Sejarah Kesehatan Nasional Indonesia. (Jakarta: Departemen

${ }^{29}$ Ibid. hlm. 28.

${ }^{30}$ Staadsblad voor Nederlandsch-Indie 1900 Batavia: Landsdrukkerij, 1901.
} Kesehatan RI, 1980). hlm. 29. 
meter dari darat atau dari tempat menaikkan dan menurunkan barang ${ }^{31}$, karantina terhadap penumpang dan kapal melibatkan syahbandar.

Pemerintah juga mengatur pemberantasan malaria yang dimulai dari penderita, pemberantasan nyamuk, dan perlindungan bagi yang sehat. Pembagian kinine sebagai obat malaria dibantu oleh guuru-guru dan pegawai Departemen Pendidikan dan Agama ${ }^{32}$. Menimbun tempat-tempat yang menjadi sarang nyamuk. Untuk penyakit-penyakit lainpun juga dilakukan berbagai upaya pencegahan. Dibangun berbagai sarana kesehatan klinik, rumah sakit, perawat, dokter. Perawatan kesehatan dilakukan dengan melibatkan seluruh masyarakat dan anak-anak sekolah juga diajarkan menjaga kesehatan.

\section{E. Kesimpulan}

Wabah penyakit yang telah lama terjadi baru mendapat penanganan serius dari pemerintah kolonial awal abad 20 yaitu dengan keluarnya berbagai ordonansi. Dalam hal ini terlihat bahwa pemerintah terlambat menangani penyakit rakyat, padahal pemerintah telah banyak mengambil keuntungan dari rakyat Karesidenan Banyumas melalui eksploitasi lingkungannya.

Ekologi Banyumas secara keseluruhan termasuk subur untuk produksi tetapi tidak demikian jika musim kemarau. Pada saat itu penyakit malaria mulai berjangkit bahkan hingga abad ke 21 ini wilayah Cilacap tidak bebas dari malaria yang menelan banyak korban. Pemerintah RI juga mengadakan berbagai usaha penyembuhan dan pencegahan. Akan tetapi kondisi lingkungan tetap menjadi penyebab utama epidemi. Sudah dua abad lebih penyakit malaria bertahan di wilayah Karesidenan Banyumas meskipun jumlah penderitanya telah mengalami penurunan.

\section{Daftar Pustaka}

Algemene Verslag 1883, Arsip Banyumas No. 1910 (ANRI)

Algemene Verslag 1883, Arsip Banyumas No. 1911 (ANRI)

\footnotetext{
${ }^{31}$ Ketentuan Tambahan UU Pes, pasal 23 ayat. 1,

${ }^{32}$ Intensief Hygiene-Werk in Medisch-Hygienische Propaganda dalam Mededelingen van Dienst der Volkgezondheid in Nederlandsche-Indie XXVII, 1938.
} hlm. 314-315. 
Beeker, P. “ Fragmenten Eener Reis Over Java Door Binnenland van Midden Java Hoofdstuk XIII Poerworedjo naar Banjoemas” dalam Tijdschrijf voor Nederlandsch Indie II adl. 7, 1850.

, "The Development of Colonial Health Care in Java: an Exploratory Introduction”, Bijdragen tot de Taal Land-en Volkenkunde KITLV 1993, deel 149.

Boomgard, Peter. Paper landschapes Exploration in the Environmental History of Indonesia. Leiden: KITLV Press, 1997.

De Jonge G.W. Kiewiet. “Tjilatjap als Malariahaard” Geneeskundige Tijdschriijft voor Nederlandsch-Indie, Deel XLII. Batavia: Java Boekh \& Drukkerij, 1902.

Depkes RI. Sejarah Kesehatan Nasional Indonesia. Jakarta: Departemen Kesehatan RI, 1980.

Geneeskundig Tijscrijf voor Nederlandsch-Indie 1911. Batavia: Javasche Boekhandel \& Drukkerij, 1911.

G.W. Kiewiet de Jonge. “Tjilatjap als Malariahaard” Geneeskundige Tijdschriijft voor Nederlandsch-Indie, Deel XLII. Batavia: Java Boekh \& Drukkerij, 1902.

Intensief Hygiene-Werk in Medisch-Hygienische Propaganda dalam Mededelingen van Dienst der Volkgezondheid in Nederlandsche-Indie XXVII, 1938.

L.M. Gondosubroto, Kenang-kenangan 1933-1950. Purwokerto: tanpa penerbit 1992.

Mausner \& Bahn. Epidemiology an Introductory Text. Philadelphia: WB Sanders Company, 1985.

Memori van Overgave 1932. Arsip Nasional RI Rel 6e.

Moh. Suryani dan Bahrin Somad (penyunting). Manusia dalam Keserasian Lingkungan. Jakarta: Fakultas Ekonomi UI, 1983.

Norman G Owen. Death and Desease in South Easth Asia. Singapore: Oxford University Press, 1987. 
P. Paverelli. De Zorg Voorde Volks Gezondhett in Nederlandsch-Indie. S’Gravenhage:Mitgeverij W van Hoewe,tt.

Residentie Banjoemas. Geneeskundig Tijdsrijft voor Nederlandsch-Indie.

Batavia:: Bruning \& Wijt, 1906.

Staadsblad voor Nederlandsch-Indie 1900 Batavia: Landsdrukkerij, 1901.

\section{Biodata:}

Alumnus S1 Jurusan Sejarah Fakultas Sastra UGM tahun 1985, S2 pada jurusan sama tahun 2000. Sejak tahun 1987 menjadi staf pengajar di Prodi Ilmu Sejarah, FISE-UNY untuk matakuliah sejarah maupun mengajar matakuliah umum (MKU). 